\title{
Towards an Analytic Theology of Charismatic Gifts: Preliminary Questions
}

\author{
Joanna Leidenhag
}

\section{Introduction}

An analytic theology of charismatic gifts would be a beneficial and timely task for analytic theologians to pursue in the service of the contemporary church. In 2011, the Pew Research Center reported over 584 million Pentecostal and Charismatic Christians, making up over a quarter of the global church and this number continues to rise rapidly. What unites these diverse groups of Christians is the centrality of the experience of the Holy Spirit through the practice of charismatic gifts (Barrett and Johnson 2002: 23-5). In addition to this important new tradition within contemporary Christianity, almost every other theological sub-tradition (Roman Catholic, Orthodox, mainline Protestants) of Christianity has something to say about charismatic gifts. Since, I know of no work already published within analytic theology on charismatic gifts, this chapter demonstrates the possibility for analytic theology "to be stretched and expanded" into this area (McCall 2015: 124). This demonstration is accomplished by exploring nine preliminary questions that an analytic theology of charismatic gifts might ask. This chapter is split into questions of definition and ontology and questions regarding epistemology. The result is a rough map for how one might construct an analytic theology of charismatic gifts, one that will hopefully serve as a springboard for new research.

\section{Questions of Definition and Ontology}

Analytic theologians value clear, working definitions of the key terms under discussion. One common way to achieve this is by outlining the necessary and/or sufficient conditions to a phenomenon or concept. The first question for an analytic theology of charismatic gifts is likely to be the hardest: 
1. How should we define "charismatic gifts"?

Identifying a charismatic gift is not a straightforward matter. Some theologians have limited the list of charismatic gifts to the most spectacular and miraculous activities (exclusively healing, prophecy, and speaking in tongues), whilst others broaden the definition to include any and every event that is normative for a Christian life (Turner 1996: 181-2; cf. Congar 2003: 1625; Moltmann 2001: 181-6). ${ }^{1}$ Even when we start with the Pauline literature, from whence we get the category $\chi \dot{\alpha} \varrho \iota \mu \alpha$, we find no clear statement for defining "charismatic gifts." "The term $\chi \alpha \varrho i \sigma \mu \alpha \tau \alpha$ (often translated as "spiritual gifts" despite having no semantic reference to the Spirit without additional context or explicit qualifiers) comes from the root $\chi \dot{\alpha} \varrho ı \varsigma$ (grace) and so indicates "a concrete expression of grace, thus a 'gracious bestowment"” (Fee 1994: 33). ${ }^{3}$ The colloquial Christian usage of this term often refers to the activities of the Holy Spirit listed in 1 Corinthians $12-14 .{ }^{4}$ Even here $\chi \alpha \varrho i \sigma \mu \alpha \tau \alpha$ seems to be very loosely applied in a nontechnical fashion to the miraculous (prophecy, healing, etc.), to the unusual (tongues), and to more mundane activities (teaching, exhortation, generous giving, words of encouragement, administration, leadership, discernment, faith, etc.) and it is strongly implied that these are representative, such that there is no fixed number of gifts (Fee 1994: 158-60; Snyder 2010: 32930; Turner 1996: 262-63). In addition, it is not immediately clear which New Testament texts and individual terms (beyond, $\chi \propto \varrho i \sigma \mu \alpha \tau \alpha$ ) refer to charismatic gifts, and which should be categorized 1994: 14).

${ }^{1}$ Mark Stibbe critiques Moltmann in his review, as promoting "anonymous Charismatics" (Stibbe

${ }^{2}$ Sixteen out of the seventeen New Testament instances of $\chi \alpha ́ \rho 1 \sigma \mu \alpha$ (or $\left.\chi \alpha \rho i ́ \sigma \mu \alpha \tau \alpha\right)$ occur in Pauline texts, the exception being 1 Peter 4:10. Since Paul does not define or explain the term for his readers, it is unlikely he coined it himself. However, we have no textually secure pre-Pauline instance of the term to aid us (Fee 1994: 32-33; Turner 1996: 262).

${ }^{3}$ Fee doubts that $\chi \alpha \dot{\rho} \rho 1 \sigma \mu \alpha$ should be translated as, "gift of the Spirit" or "spiritual gifts," since it is only in 1 Cor. 12:8-10 that the $\chi \alpha \rho i ́ \sigma \mu \alpha \tau \alpha$ are explicitly tied by Paul to the concrete manifestations of the Spirit in the community. Instead, Fee argues that $\chi \alpha ́ \rho ı \sigma \mu \alpha$ is a broader category for "graces" such as eternal life (Rom. 6:23, the privileges given to Israel (Rom. 11:29), celibacy and marriage (1 Cor. 7:7), and deliverance from deadly peril (2 Cor. 1:10) (Fee 1994: 33-5).

${ }^{4}$ See, Rom. $1: 11$ where $\chi \alpha ́ p ı \sigma \mu \alpha$ is qualified by the noun $\pi v \varepsilon v \mu \alpha \tau$ เ $\chi \alpha \rho i ́ \sigma \mu \alpha \tau \alpha$, are described as "manifestations of the Spirit" (Fee 1994: 33). 
under a different heading, for example, graces, ecclesial offices, natural gifts, or fruits of the Spirit.

I do not claim to have overcome these substantial exegetical difficulties but offer the following criteria as a provisional, working definition of charismatic gifts:

(CG1). A phenomenon is a charismatic gift only if it is a gift of grace.

(CG2). A phenomenon is a charismatic gift only if the Holy Spirit is the primary, but not the sole, agent.

(CG3). A phenomenon is a charismatic gift only if it or its effects are concretely perceivable.

(CG4). A phenomenon is a charismatic gift only if it builds up the Christian community.

(CG5). A phenomenon is a charismatic gift only if it is realized in the context of eschatological expectation.

As the most direct translation of $\chi \alpha \varrho i \sigma \mu \alpha \tau \alpha$ and as a central part of Paul's overall argument in 1 Corinthians, (CG1) is a necessary, but insufficient condition for defining a charismatic gift. Together (CG1) and (CG2) rule out any phenomenon that comes exhaustively from the natural powers of the recipient, and so a person cannot deserve a charismatic gift or gain merit from receiving one. Similarly (CG5) denotes a posture of receptivity and an openness to being surprised as the human person cooperates with, but cannot conjure, the activity of the Holy Spirit (Blanenhorn 2014: 376). However, in contrast to other miracles, a gift to a creature involves the co-operation of the recipient, such that the Holy Spirit may be the primary but not strictly speaking the sole agent of the phenomenon. Since there is a human agent involved in the reception and performance of a charismatic gift it seems fair to say, as in (CG3), that these will be concretely perceivable in some way. This is not to say that charismatic gifts are always publicly self-evident, nor transparent in nature, but only that there is something to remark upon. How this co-operation between the agency of the Holy Spirit and the human person is best articulated would be a fruitful area for further research.

(CG4) is probably the most emphasized criteria for charismatic gifts within the literature, and it places at least two constraints and one implication upon any theology of charismatic gifts. 
The first constraint is that in service of the Body of Christ, a charismatic gift must, directly or indirectly, declare the lordship of Jesus Christ. This is closely connected to (CG5), where eschatological expectation anticipates the glorious return of Jesus Christ (Smith 2010: 44; Albrecht and Howard 2014: 244). ${ }^{5}$ The second constraint is that virtues, such as hope, faith, and love (1 Cor. 13), must remain at the center of the practice of charismatic gifts. In light of these criteria, some scholars go so far as to define the church as "essentially charismatic" and "a charismatic organism" (Snyder 2010: 328; cf. Küng 1965: 41-61). An important area for further research is how far charismatic gifts may be given primarily to congregations, rather than individuals, and considered a group liturgical action (Leidenhag, forthcoming). This may have interesting implications for questions of discernment, authority, and church unity.

2. What type of thing is a charismatic gift?

The above five criteria have not settled the question as to what type of thing a charismatic gift is: an act, a quality, a disposition, a habit, or a power? This is not a question that has been given much attention, at least not since medieval scholasticism (Blanenhorn 2014: 376). This modern lacuna is unfortunate since differing answers to hotly disputed pastoral questions (such as how charismatic gifts relate to ecclesial authority, personal identity, or whether they endure over time) assume different ontologies of charismatic gifts. By briefly considering Thomas Aquinas's discussion of this question, I echo the thesis of Bernhard Blanenhorn, O.P. (2014) that charismatic gifts have a two-fold metaphysic, as actions of the Holy Spirit for which a person can also acquire a receptive habitus or sensitivity.

Thomas Aquinas (1920) distinguishes between gratuitous grace (gratia gratis data), which he associates with the list of phenomena in 1 Corinthians 12 , and sanctifying grace that is a direct effect of the indwelling of the Holy Spirit that produces the spiritual gifts that perfect the virtues, which he associates with the list of phenomena in Isaiah 11:2-3 (I-II.q111.a1). The latter, the

51 Cor. 1:6-7, provides a clear link between the charismata and eschatological expectation. See also, Rom. 8:23, 2 Cor. 1:22, 5:5, Eph. 1:13f, and Heb. 6:4f. 
spiritual gifts (sanctifying grace), are a receptive habitus resulting from infused grace and a disposition to be acted upon by the Holy Spirit (I-II.q55.a2, q68.aa1\&3). By contrast, Thomas denies that charismatic gifts (gratuitous grace), such as prophecy, are an active habitus, similar to natural agential cognition, since charismatic gifts surpass natural capacities and are not at the disposal of the human to actualize (II-II.q171.a2; cf. Blankenhorn 2014: 387-90). Instead, Thomas writes, the "principle of things that pertains to supernatural knowledge, which are manifest through prophecy, is God himself," and not primarily the human agent, to whom a charismatic gift is only a "passion" or "disposition for being acted upon" (II-II.q171.a2 sed contra). ${ }^{6}$ This concurs with CG1 and CG2 above.

However, this neither helps to explain why it is that some individuals seem to have a greater receptivity for these actions, which charismatic and Pentecostal communities often refer to as a special anointing, nor why eschatological expectation is necessary, nor what role free human action plays in the manifestation of a charismatic gift. Thus, one might justifiably complement this view of a charismatic gift as an act of the Holy Spirit, with a receptive habitius such that the human agent has an "increased sensitivity, receptivity, and docility" to the Spirit's actions (Yong 2005: 293-94). ${ }^{7}$ This inner receptivity to the Spirit will itself be an act of the Spirit, but one that the person can resist or receive with hopeful expectation for its future operation. A role of a babitus could provide a link between charismatic gifts and sanctification, as is common in notions of charismatic gifts as a sign of the Spirit's indwelling or evidence of salvation.

However, it does not entail this link, which Thomas objected to on the grounds that charismatic

\footnotetext{
${ }^{6}$ This is true even for Christ's humanity, see Aquinas (III.q13.a2; II-II.q171.a2; qq.176-78); Blankenhorn (2014: 394-5).

${ }^{7}$ For example, Aquinas describes that "a certain disposition (habilitas) to be acted upon again" or "illuminated again more easily" remains in the prophet, after the Holy Spirit has acted in provide supernatural knowledge. (1920: II-II.q171.a.2.ad.2). Blankenhorn (2014) refers to this as a "quasi-natural after-effect of a supernaturally received cognition" (399).
} 
gifts were exclusively for evangelism and not for the perfection of the recipient themselves (Blankenhorn 2014: 407-9, 418). ${ }^{8}$

3. Are charismatic gifts supernatural or natural phenomena? Since Christians view "nature" as a creation sustained, providentially ordered, and intimately related to God, it makes little sense to view the ordinary processes of the natural world as autonomous from or in competition with God. As a result of this doctrine of creation, the definition and even validity of the category of the supernatural has undergone substantial debate in recent decades. In a discussion of charismatic gifts, Amos Yong (2005) argues that the "early modern distinction between 'natural' and 'supernatural' should be abandoned when one talks about the charismata" (294). Leading analytic theologian, Michael Rea, characterizes the visions and voices reported within the Vineyard movement, and even the most paradigmatic examples of special revelation (i.e. Moses and the burning bush), as "purely natural" requiring no "special causal contact" between God and humanity (2018: 98, 101-2, 106-7).

Should one use Rea's model to develop an account of charismatic gifts as purely natural phenomena? Although retaining a role for the human agent is important, a purely natural account of charismatic gifts will struggle to satisfy (CG1) and (CG2). Rea denies that God is the "immediate stimulus" or "direct cause" for these events and uses an ambiguous appeal to providence to maintain their divine origin (2018: 107). This approach might be metaphysically possible, but it does not seem theologically beneficial. The providence of God may arrange events to occur solely through the powers that are created as proper to the nature of a thing, but to claim that something is "of grace" or a (sometimes, temporary) "gift," is to claim that a particular event exceeds the powers of a natural agent.

${ }^{8}$ However, Thomas does not exclude the possibility that the gift of tongues may be habitual (1920:IIII.q176.a2.ad3) and implies the Christ had such a habitual gift of xenoglossia (1920: III.q7.a7.ad.3); Blankenhorn (2014: 398). 
I see no reason why one cannot hold divine activity to work in a diversity of ways. God might both create and uphold the ordinary powers of nature as described by the natural sciences or the doctrine of providence, and God might perform actions that empower creatures beyond (hence, "super-") these ordinary powers (hence, "-natural") to achieve some surprising and, scientifically inexplicable, outcome. Rather than collapsing all of God's activities into one paradigm, it seems far more theologically beneficial to mark the different ways in which God's agency manifests in and through creation (Abraham 2017). If one accepts this view of what is meant by "natural" and "supernatural," then it seems clear that charismatic gifts, and indeed all forms of grace that go beyond the powers granted to the essence of a creature, should be considered supernatural.

To be clear, since there is so much confusion on this topic, to say that charismatic gifts extend the powers that human beings have in and of themselves is not to say that human agency must be suspended or violated in some way. Thus, a charismatic gift may not be self-evidently or transparently supernatural, even to the recipient. Despite the primary agency and empowerment of the Spirit, the co-operation of fallen agents means that the gifts remain vulnerable to misinterpretation and misuse in certain ways. To affirm the supernatural quality of charismatic gifts is not to deny this, but simply to maintain (CG1) that these are instances of grace, and (CG2), that the primary (but not sole) agent is a supernatural (Uncreated) one.

4. Can charismatic gifts be learned or practiced? Sarah Coakley has emphasized that liturgical learning is not like immediate perception, but a "complex means of training the mind and senses, over time, in order to come into a right relation with God" (Coakley 2013: 137-8). Is the same true of charismatic gifts? Are the gifts more like liturgical learning or immediate perception? On the one hand, the idea of learning a charismatic gift seems contrary to the gratuitous and coming-from-without nature of these phenomena (CG1). Additionally, training may allow for the possibility of a new spiritual elite and undermine the equalizing potential of charismatic gifts within the church. On the other hand, the intentional 
pursuit of God in contemplative prayer and ascetic practices is clearly a part of charismatic spirituality, often as a means of expectant and preparatory waiting for the Spirit (CG5) (Albrecht and Howard 2014: 240). Yong (2005), affirms that "the charismata can be cultivated and developed" through practice and mentorship (295). How are we to make sense of this tension? In her influential study, When God Speaks Back, T.M. Luhrmann emphasizes this knowledge-how aspect of how charismatic gifts function within the Vineyard Church. She writes that, for the Christians she encountered, coming to know God personally "was more like learning to do something than to think something. I would describe what I saw as a theory of attentional learning," whereby members of the church learnt to pay attention to God in certain ways and learnt "to identify some thoughts as God's voice, some images as God's suggestions, some sensations as God's touch or the response to his nearness" (2012: xxi, see also 40-1, 60, 371-2). Luhrmann calls this "new Christian theory of mind" a "participatory theory of mind," because it teaches participants that the barrier between their own mind and God's is porous in certain ways (Luhrmann 2012: 40; cf. Rea 2018: 93-6, 106-7). In this, Luhrmann describes the learning to perceive God's presence, to receive a word of prophecy, or be "nudged" to act in a certain way (all activities that may be categorized as charismatic gifts, although Luhrmann never uses the term), as akin to learning to read a sonogram or become a professional sommelier. Charismatic gifts may then be a learnt form of perception. What this indicates is that, the Spirit's appearance, movement, or communication must remain gratuitous, uncontrollable, and beyond any human capacity to "conjure up," but that humans can still learn to perceive, sense, or be correctly attuned to such movements of the Spirit, and they can do so to greater or lesser degrees. This seems to fit with the two-fold metaphysic argued for above whereby the charismatic gifts are actions of the Spirit mediated through the receptive habitus of the human, the latter of which may be developed and honed but remains useless without the former. The unearned nature of charismatic gifts does not entail that they are also unlearned. 


\section{Epistemological Questions}

The first epistemological question for any community where a charismatic gift is reported is:

5. How does a community know that a reported charismatic gift is the work of the Holy Spirit, and not another spirit - supernatural, demonic, psychological, alcoholic, or other that may explain the phenomena?

The literature in analytic epistemology of religion cannot exhaustively adjudicate this important area of spiritual discernment, but it may offer some aid. Let us accept the classic definition of knowledge as a justified true belief. Whether the belief that it is the Holy Spirit who is the primary agent behind a phenomenon is a true belief seems beyond our capacity to be certain about, although one might build a cumulative case to access the probability of the claim (Middlemiss 1996: 194-236). Thus, any report of a charismatic gift will always remain provisional. Focusing instead on the issue of epistemic justification, we might rephrase this question to:

5a. When is the community, justified in believing that a charismatic gift is authentically the work of the Holy Spirit?

As Estrelda Alexander (2015) describes, it is important that this act of discernment "is a corporate responsibility," and not the responsibility of any one individual (143). When a person perceives themselves to have received a charismatic gift that does not immediately manifest in any other publicly discernible way, it is likely that she will report this experience verbally. Thus, we move into the epistemology of religious testimony. In believing the speaker who claims to have a charismatic gift, the community is authorizing the activity of the speaker, as well as ascribing justification, warrant, and possibly authority to her assertions. Should the standards for presumptive credulity remain the same as in more mundane testimonial interactions? As with all accounts of testimony, the speaker is capable of deception and error, and second-personal knowledge or the standing of the person within the community may play an important role in the community's discernment process. 
Whilst there are likely to be additional sources of justification, such as the public manifestation of the gift, a memory of such events previously in the life of the community, or corroboration with other accepted authorities (e.g. Scripture), I do not think that these are taken as necessary within many epistemic communities accustomed to discerning the presence of a charismatic gift. Instead, such communities often practice a Reidian non-reductionist account of testimony where, as with children, there are presumptions of veracity and credulity (Reid 1997: 6.24; cf. Wolterstorff 2000: 163-84). Indeed, charismatic theologians often give a normative role to children, childlikeness, and playfulness in their accounts of testimony and charismatic gifts. But is this doxastic practice justified? According to Reid (1997), both of these principles are implanted as innate mental faculties by God in order that "we should be social creatures, and that we should receive the greatest and most important part of our knowledge by the information of others" (193-4). This approach not only provides an externalist justification of testimony, but suggests that the social benefits of testimony make it a preferable form of knowledge acquisition. In the case of charismatic gifts, which by definition builds up the community, it seems preferential then that not all members of the community receive all the gifts, but that they must trust one another's testimony at various points. ${ }^{9}$ For this line of inquiry to be developed further analytic theologians may need more robust accounts of epistemic communities, in which testimonials about charismatic gifts can be appropriately discerned (Hankinson Nelson 2013).

However, before a testimony of a charismatic gift can be made, a person themselves needs to believe that they have received a specific gift. Therefore, the related question is:

5c. When is an individual justified in believing that she is a recipient of a charismatic gift?

${ }^{9}$ There is some irony in the epistemic fit between a Reidian account of testimony with charismatic gifts since, as Jon Ruthven (1993) has argued, B.B. Warfield's cessationism is also heavily reliant upon Reid's Scottish common-sense philosophy (44-52). 
Authentic charismatic gifts are probably best categorized, from the perspective of the recipient, as a religious experience. More controversially, many recipients of charismatic gifts take this to be a perceptual religious experience. That is, charismatic gifts are a religious experience whereby the subject encounters the Holy Spirit or perceives a communication from God. William P. Alston (1991) has argued that, in a way parallel to how physical sense perception justifies beliefs about ordinary objects, a person is rationally justified in believing that their apparent non-sensory perception of God's presence is veridical and the beliefs resulting from this perception are also justified. There is substantial overlap between Alston's way of justifying belief in mystical perception and how many recipients of charismatic gifts describe their religious experience, as a non-inferential doxastic practice arising directly from spiritual perception. Analytic theologians could, therefore, employ Alston's work on religious experience to argue that a person is justified in believing that she has received a charismatic gift just in the case that she perceives this to be so. In addition, however, it must be remembered that charismatic gifts are given for the good of a community and so it may well be that the community has epistemic authority in this case of discernment. This may entail that the individual is justified in offering her testimony/interpretation of the phenomenon but withholds judgement until the community discerns whether or not her prophecy, word of knowledge/wisdom, healing, tongues and interpretation, is a special act of the Holy Spirit in their midst.

6. What type of knowledge can be obtained from a charismatic gift? What makes charismatic gifts frightful to some and exciting to others is the claim that new or confirmatory religious knowledge can be gained from a charismatic gift. Some gifts, such as words of knowledge, words of wisdom, prophecy, and speaking in tongues with interpretation, seem to be a form of special revelation. The reception of these charismatic gifts involves the use of the recipient's cognitive faculties as a belief-forming process. Moreover, this special revelation or insight to an individual does not appear to be a mere commentary on God's activity, but often functions as a herald or even means by which the Spirit achieves God's purposes at a specific 
time and place. It is these further claims, that beliefs obtained from a charismatic gift have warrant, can be taken as evidence, hold authority, and even release divine power, which makes careful discernment of whether a charismatic gift is the work of the Holy Spirit so important.

Above I claimed that from the perspective of the recipient charismatic gifts are a type of religious experience in which a person claims to have an experience of encounter with the Holy Spirit. As Michael Sudduth (2009) notes, this is in contrast to the post-Kantian liberal Protestant trend to view religious experiences as mystical, apophatic, and non-cognitive natural phenomena interpreted as religiously significant for the individual (220-1). The only charismatic gift that could match this form of religious experience is a sub-type of glossolalia reserved for private prayer and emotional expression, which cannot be articulated or even interpreted into semantic content. ${ }^{10}$ Apart from this phenomenon, charismatic gifts seem to be a thoroughly cognitive form of religious experience that generates, or at least claims to generate, a variety of types of knowledge about God or to receive knowledge about the world from God. Happily, the latter half of the twentieth century has seen an increasing number of theologians and philosophers maintain that religious experience can also be cognitive, often as a form of perception (e.g., Ballie 1939: 166-77; Hick 1971: ch.7; Alston 1991; Swinburne 2013: ch.13).

Intuitive perception is commonly described as analogous to when we perceive the presence of another mind and obtain knowledge by acquaintance, rather than through propositions. This second-personal knowledge appears to be of immediate advantage to theology, since it suggests that God can be known not merely as an object of perception but as a person with whom humans can engage in an inter-personal relationship. As such, secondpersonal accounts of religious experience have become popular amongst analytic theologians

\footnotetext{
${ }^{10}$ Tongues (glossolalia) seem to come in a variety of forms and can refer to speaking in unknown or angelic languages, speaking in another known language (xenolalia), a language of private prayer, and free doxological speech amongst the congregation which functions as a herald of the Spirit's presence, and simultaneously symbolises humanity's remaining distance from God and a promises for eschatological renewal (Turner 1996: 312-13).
} 
(e.g., Stump and Pinsent 2013). This area of research could be particularly helpful in providing a fuller account of charismatic gifts.

Second-personal accounts of knowledge of God and religious experience tend to rely upon recent psychological research on shared or joint attention, sometimes called “intersubjective perception” (Hobson 2005: 190). Joint attention occurs when two or more participants are aware of the other's awareness and are introspectively aware of the others awareness of their own awareness (Green 2009: 459-60). This can be dyadic, where both parties attend to the other as in reciprocal smiling, or triadic, where both parties attend to the same object, often co-ordinating by pointing or by some other physical gesture. Importantly, shared attention gives a "heightened opportunity for the communication of affect," so that learning how the other participant feels is essential to the overall communicative experience (ibid., 461).

In the case of charismatic gifts, attention may be shared dyadically with the Holy Spirit, such that the congregation become aware of the Spirit's presence, love, or voice, or triadically as the Spirit may prompt a person's attention towards a third object, such as, a person in need, the persistence of a certain sin in one's life, or a passage of Scripture. ${ }^{11}$ The strength of the paradigm of joint attention as an account of charismatic gifts is that it allows for substantial similarities to other forms of religious experience and it has traction with the descriptions from Charismatic and Pentecostal communities of the gifts as including a distinctive type of intuitive, sensitive, and receptive "attention" given to the Holy Spirit (Albrecht and Howard 2014: 241). In particular, as a situationally irreducible form of interpersonal knowledge, testimony regarding joint attention lends itself to social cohesion (CG4) and the kinds of narratives that are common within charismatic communities as a way of scrutinizing and transmitting beliefs formed on the basis of charismatic gifts.

\footnotetext{
${ }^{11}$ Green (2009) describes "a triadic experience, for example, by the divine showing a prophet the fate of a nation, and so on" (462).
} 
Whilst knowledge by acquaintance appears to be a central and essential form of knowledge obtained through charismatic gifts, it should not exhaust the forms of knowledge obtained through the gifts. Instead a place needs to be maintained for propositional knowledge and knowledge-how to hear or encounter the Spirit (see question 4 above). In what follows, I will focus on propositional knowledge and explore the questions of warrant, evidence, and authority that quickly arise.

7. Do beliefs obtained from charismatic gifts have warrant? The concept of warrant, as developed by Alvin Plantinga, is that which turns mere belief into knowledge, but unlike justification it is conferred upon the beliefs directly, rather than upon the subject of those beliefs. An extension of Plantinga's defense of the rationality of "the great things of the gospel" to beliefs held on the basis of charismatic gifts would be no insignificant task (Plantinga 2000: 244). Plantinga argues that a person can rationally hold beliefs by appealing to a belief-producing process of a special kind, namely the "inner testimony" or "inner instigation" of the Holy Spirit as "a supernatural gift" (245-6, 251). Such beliefs, according to Plantinga, are "properly basic" and require neither argument nor evidential basis from other propositions, nor even an argument from religious experience although they are formed on the occasion of a religious experience (259). I see no reason why Plantinga's model, which he apples to the gift of faith, could not be extended to include other doxastic charismatic gifts.

The first question facing a Reformed Epistemologist's account of charismatic gifts is: When beliefs are obtained by means of a charismatic gift, are these beliefs produced by cognitive processes functioning properly? An affirmative answer to this question would be a direct refutation of characterizations of charismatic gifts as irrationality (a symptom of madness, mass hysteria, the manipulation of a malevolent spirit, or deceptive self-aggrandizement), all of which assume that charismatic gifting is not what proper function looks like. Regardless of what one thinks about Reformed Epistemology overall, this is surely an important theological question regarding the relationship of charismatic gifts to the imago Dei and God's providential plan for 
humanity. If charismatic gifts are representative of regenerated and eschatological proper cognitive functioning, then an important second question may be: What is the proper cognitive environment for which this particular cognitive process was designed? It may well be that, unlike other cognitive processes that God has designed for human beings to obtain knowledge, the gathered congregation is the primary or even the only appropriate environment in this case.

\section{Can charismatic gifts be rightly treated as evidence?}

One of the most striking and controversial aspects of charismatic gifts arises from their employment as evidence for other beliefs or states of affairs, such as the existence of God, the recipients own state of salvation, or a Spirit-baptism distinct from water-baptism. John Locke (1975) argued that the doxastic gifts (e.g., prophecy, dreams, visions, words of knowledge and wisdom) required further evidence from publicly available gifts (healings, miracles) (bk. 4, ch.19). The idea that publicly available charismatic gifts provide evidence for the credibility of new religious knowledge, also lies at the heart of B.B Warfield's cessationist argument against the existence of charismatic gifts since the closing of the biblical cannon (Ruthven 1993: 43). This history of correlating charismatic gifts with evidence provides a surprising point of contact with analytic philosophy of science which, through the historic influence of positivism and evidentialism, has been highly invested in the concept of evidence (most often) as that which justifies belief. It is perhaps also one of the main reasons that charismatic gifts such as glossolalia (speaking in tongues) have been a major focus of empirical research into religious phenomena (Newberg, et al. 2006; Newberg and Waldman 2009; Mill 1986).

The correspondence between charismatic gifts and evidence may be surprising because evidence is often closely related to objectivity; where a person is objective if their beliefs are determined by evidence and not, for example, texts or teaching whose authority is obtained through tradition, personal attachment, or conviction. There seems to be a tension in the notion that charismatic gifts are a form of evidence defined and constrained by reports of their existence 
in Scriptural texts, arising in the context of community-building and religious conviction. What form of evidence, then, are charismatic gifts?

There is a wide range of definitions of "evidence" from physical objects (a bloody knife at a crime scene) to perceptual experiences (seeing the murderer stab the victim). Trent Dougherty (2017) argues that at the bottom of any account of evidence is an experience, perhaps even a mental event generated by the imagination in response to certain stimuli (241-2). Charismatic gifts, following Dougherty's definition of evidence, may be characterized as testimonial evidence (237). Similarly, Paul K. Moser (2017) (although he never mentions charismatic gifts) describes the experiential aspect of the inner witness of the Holy Spirit as not only "experiential evidence of God's intervention for a recipient," but also the "sole evidential foundation for believing in God and for believing that God exists" $(119,121)$. The debates within analytic philosophy regarding what kinds of things count as evidence and how evidence relates to belief would be a fruitful area for an analytic theology of charismatic gifts to pursue.

And yet another question emerges: what are charismatic gifts evidence for? Again, there is a wide variety of philosophical accounts of the relationship between evidence and hypotheses, but it is the narrative account that seems best suited to the case of charismatic gifts (Dougherty 2017: 242). We see this narrative relationship between evidence and hypothesis in the interweaving of Scripture within contemporary testimonies regarding charismatic gifts to generate new "narrative knowledge" (Smith 2017: 610). In Charismatic and Pentecostal communities, this is captured by the hermeneutical slogan "this-is-that," which frames contemporary events as an echo or fulfilment of promises from Scripture (McPherson 1923; Stibbe 1998). Scripture then provides the best story about the contemporary phenomena and the contemporary phenomena function as evidence for the propositions of Scripture (Smith 2010: 23). In this way, charismatic gifts can function as a form of evidence, without jettisoning the authority of Scripture, personal attachment or conviction. 
9. What type of epistemic authority do charismatic gifts carry or bestow upon the recipient? The question of epistemic authority lies at the heart of a great many disputes regarding charismatic gifts. ${ }^{12}$ As mentioned above, Protestant cessationism reduces to a concern that a charismatic gift challenges the sufficiency of Scripture and some wings of the Roman Catholic Church worry that charismatic gifts undermine ecclesial hierarchy. ${ }^{13}$ This is largely because the claims of direct inspiration or anointing by the Holy Spirit in the case of a charismatic gift appear indistinguishable from many Protestant articulations of the authorship of Scripture and many Roman Catholic notions of the power granted by ordination. This has given charismatic gifts great potential to be employed and abused by anti-establishment, self-autonomous movements, and by those in authority throughout the church's history (Tanner 2006). It is unsurprising, then, that arguments have not often revolved around what authority a charismatic gift bestows, since this is assumed on both sides, but instead have revolved upon whether a charismatic gift is authentically present (question 5).

The power of charismatic gifts to grant spiritual authority to the socially disenfranchised or economically oppressed margins of society is, and will likely remain, a central part of their importance and appeal across the globe. As Albrecht and Howard (2014) describe in the context of Pentecostalism, "[l]eadership in a congregation may arise at any moment as one sister or brother becomes the vehicle for the authoritative word or touch of God in the midst of a gathering” (244). Whilst, as Smith (2010) notes, the Pentecostal epistemological testimonial claim, "I know that I know that I know," prioritizes narrative and allows space for testimony and

${ }^{12}$ There is a great deal of literature dealing with political/social authority, rather than epistemic authority, of charisms arising out of Max Weber's (1964) sociological description of charisms as a form of domination and the "the routinization of charisma" in the early church (363-73).

${ }^{13}$ Thus, B.B. Warfield writes that the actions of the Holy Spirit are not rational evidence themselves but feeling that which accompanies the evidence of Scripture (Ruthven 1993: 14-15, 53). This seems approximately in line with Paul Moser's (2017) work on the testimony of the Holy Spirit as "epistemically confirming God's reality and work" (114). In Counterfeit Miracles, Warfield also wrote that the gifts were given "to authenticate the Apostles as the authoritative founders of the church" (cited in Ruthven 1993: 72). As D.A. Carson (1987) concludes, Warfield's "argument stands up only if such miraculous gifts are theologically tied exclusively to a role attestation; and this is demonstrably not so" (156). For an overview of the Roman Catholic/Pentecostal dialogue over the authority that charismatic gifts, see, Kärkäinen (2001). 
witness within a communities doxastic practices, it may also be used as a claim for the authority of introspection and a defense against skeptical attacks or critical reflection $(50,62-71)$. However, it would be a mistake to conclude that charismatic gifts, even when authentic, grant absolute authority to an autonomous individual over and against all other socially agreed forms of epistemic and religious authority. Since a charismatic gift is (by definition) given for the edification of the church and the community is where an individual learns to receive charismatic gifts, she has good pre-emptive reasons to submit herself to the authority of the community in discerning and interpreting the gift. In so far as this community has submitted itself to the authority of Scripture and to certain appointed leaders, it has pre-emptive reasons to submit any prophetic word or new propositional knowledge to these other authoritative sources. Questions of epistemic authority clearly abound in the context of charismatic giftings and are essential to the communal practice of such phenomena.

\section{Conclusion}

This essay has shown that analytic theology holds fruitful resources for answering some of the urgent questions facing the church on the matter of charismatic gifts. Further topics of investigation still remain, such as, what doctrine of God is implicit within the theology and practice of charismatic gifts; this could pertain to the Triunity of God, the personhood of the Holy Spirit, the metaphysics of indwelling, the hiddenness of God, and countless other areas. There is also good reason to think that analytic theology itself will benefit from giving greater attention to charismatic gifts, as these gifts are a central part - perhaps even the spiritual foundation - of the church's worship and knowledge of God. Charismatic gifts should then provide resources that constrain, modify, and breathe life into the models constructed by analytic theologians.

\section{References}

Abraham, W. J. (2017), Divine Agency and Divine Action: Exploring and Evaluating the Debate, Oxford: Oxford University Press. 
Albrecht, D. E., Howard, E. B. (2014), 'Pentecostal Spirituality', in C. M. Rodeck and A. Yong (eds) The Cambridge Companion to Pentecostalism, 235-53, Cambridge: Cambridge University Press.

Alexander, E. Y. (2015), 'The Spirit of God: Christian Renewal in African American

Pentecostalism', in J. W. Barbeau and B. F. Jones (eds), Spirit of God: Christian Renewal in the Community of Faith, 128-46, Downers Grove: InterVarsity Press.

Alston, W. (1991), Perceiving God, Ithaca: Cornell University Press.

Aquinas, T. (1920), Summa Theologica, 2nd edn, Fathers of the English Dominican Province (trans). Available online: http://www.newadvent.org/summa/2001.htm

Ballie, J. (1939), Our Knowledge of God, New York: Charles Scribner's Sons.

Barrett, D. B., and Johnson, T. M. (2002), 'Annual Statistical Table on Global Mission: 2002', International Bulletin of Missionary Research 26 (1): 23-5.

Blanenhorn, B. (2014), 'The Metaphysics of Charisms: Thomas Aquinas, Biblical Exegesis and Pentecostal Theology', Angelicum 91 (3): 373-424.

Carson, D. A. (1987), Showing the Spirit: Theological Exposition of 1 Corinthians 12-14, Grand Rapids: Baker Academic.

Coakely, S. (2013), 'Beyond 'Belief': Liturgy and the Cognitive Apprehension of God', in T. Greggs, R. Muers, and Z. Zahl (eds) The Vocation of Theology Today, 130-45. Eugene: Wipf \& Stock.

Congar, Y. (2003), He Is Lord and Giver of Life: I Believe in the Holy Spirit, volume 2, trans. D. Smith, New York: Crossroad Publishing.

Doughtery, T. (2017), 'Evidence and Theology', in W. J. Abraham and F. D. Aquino (eds) The Oxford Handbook of the Epistemology of Theology, 236-52. Oxford: Oxford University Press.

Fee, G. (1994), Empowering Presence: The Holy Spirit in the Letter of Paul, Peabody: Hendrickson Publishers.

Green, A. (2009), 'Reading the Mind of God (without Hebrew Lessons): Alston, Shared Attention, and Mystical Experience', Religious Studies 45: 455-79.

Hankinson Nelson, Lynn. (2013), 'Epistemic Communities', in L. Alcoff and E. Potter (eds) Feminist Epistemologies, 121-60, New York: Routledge.

Hick, John. (1971), Arguments for the Existence of God, New York: Herder \& Herder.

Hobson, P. R. (2005), 'What puts the jointness in joint attention?' in N. Elian, C. Hoerl, T.

McCormack, and J. Roessler (eds) Joint Attention: Communication and Other Minds, 185-204. Oxford: Oxford University Press.

Kärkäinen, V. (2001), 'Church as Charismatic Fellowship: Ecclesiological Reflections from the Pentecostal-Roman Catholic Dialogue', Journal of Pentecostal Theology 9 (1): 100-21.

Küng, H. (1965), 'The Charismatic Structure of the Church', Concilium 4: 41-61.

Leidenhag, Joanna. (forthcoming), 'For We All Share in One Spirit: Charismatic Gifts as Liturgical Group Actions," TheoLogica: An International Journal for Philosophy of Religion and Philosophical Theology. 
Locke, J. (1975), The Clarendon Edition of the Works of John Locke: An Essay Concerning Human Understanding, ed. Peter Nidditch, Oxford: Oxford University Press.

Luhrmann, T. M. (2012), When God Talks Back: Understanding the American Evangelical Relationship with God, New York: Random House.

McCall, T. H. (2015), An Invitation to Analytic Christian Theology, Downers Grove: IVP Academic.

McPherson, A. S. (1923), This is That: Personal Experiences, Sermons, and Writings of Aimee Semple McPherson, Los Angeles: Echo Park Evangelistic Association.

Middlemiss, D. (1996), Interpreting Charismatic Experience, London: SCM Press.

Mills, W. E. (1986), Speaking Tongues: A Guide to Research on Glossolalia. Grand Rapids: Eerdmans.

Moltmann, J. (2001), The Spirit of Life: A Universal Affirmation, Minneapolis: Fortress Press.

Moser, P. (2017), 'The Inner Witness of the Holy Spirit', in W. J. Abraham and F. D. Aquino (eds) The Oxford Handbook of the Epistemology of Theology, 111-25, Oxford: Oxford University Press.

Newberg, A. and Waldman, M. R. (2009), How God Changes Your Brain, New York: Ballantine Books.

Newberg, A. B., Wintering, N. A., Morgan, D., and Waldman, M. E. (2006), 'The Measurement of Regional Cerebral Blood Flow during Glossolalia: A Preliminary SPECT Study', Psychiatry Research: Neuroimaging 148: 67-71.

Pew Research Center. (2011), 'Global Christianity - A Report on the Size and Distribution of the World's Christian Population', Accessed June 30, 2019. Available online: https://www.pewforum.org/2011/12/19/global-christianity-exec/

Plantinga, A. (2000), Warranted Christian Belief, Oxford: Oxford University Press.

Rea, M. (2018), The Hiddenness of God, Oxford: Oxford University Press.

Reid, T. (1997), An Inquiry into the Human Mind on the Principles of Common Sense, ed. D. R. Brookes. Edinburgh: Edinburgh University Press.

Ruthven, J. (1993), On the Cessation of the Charismata: The Protestant Polemic on Postbiblical Miracles, Sheffield: Sheffield Academic Press.

Smith, J. K. A. (2010), Thinking in Tongues: Pentecostal Contributions to Christian Philosophy. Grand Rapids: Eerdmans.

Smith, J. K. A. (2017), 'Pentecostalism', in W. J. Abraham and F. D. Aquina (eds) The Oxford Handbook of the Epistemology of Theology, 606-18, Oxford: Oxford University Press.

Stibbe, M. (1994), 'A British Appraisal', Journal of Pentecostal Theology 4: 5-16.

Stibbe, M. (1998), 'This is That: Some Thoughts Concerning Charismatic Hermeneutics', Anvil: An Anglican Evangelical Journal for Theology and Mission 15 (3): 181-93.

Stump, E. and Pinsent, A., eds (2013), ‘The Second-Personal in Philosophy of Religion' [Special Issue] European Journal for Philosophy of Religion 5 (4). 
Sudduth, M. (2009), 'The Contribution of Religious Experience to Dogmatic Theology', in O. D. Crisp and M. C. Rea (eds) Analytic Theology: New Essays in the Philosophy of Theology, 214-32, Oxford: Oxford University Press.

Swinburne, R. (2013), The Existence of God, Oxford: Clarendon Press.

Snyder, H. (2010), 'Spiritual Gifts', in G. R. McDermott (ed) The Oxford Handbook of Evangelical Theology, 325-37, Oxford: Oxford University Press.

Tanner, K. (2006), 'Workings of the Spirit: Simplicity or Complexity?' in M. Welker (ed) The Work of the Spirit: Pneumatology and Pentecostalism, 87-105. Grand Rapids: Eerdmans.

Turner, M. (1996), The Holy Spirit and Spiritual Gifts: Then and Now, Carlisle: Paternoster Press.

Weber, M. (1964), The Theory of Social and Economic Organization, trans. A. M. Henderson and T. Parsons. New York: Free Press.

Wolterstorff, N. (2000), Thomas Reid and the Story of Epistemology, Cambridge: Cambridge University Press.

Yong, A. (2005), The Spirit Poured Out on All Flesh: Pentecostalism and the Possibility of Global Theology, Grand Rapids: Baker Academic. 